\title{
Kwetsbare waardigheid. Ethiek aan het begin en einde van het leven
}

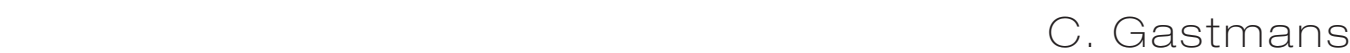

208 blz., Brasschaat: Pelckmans Uitgevers, 2021 (ISBN 978-94-6337-281-7)

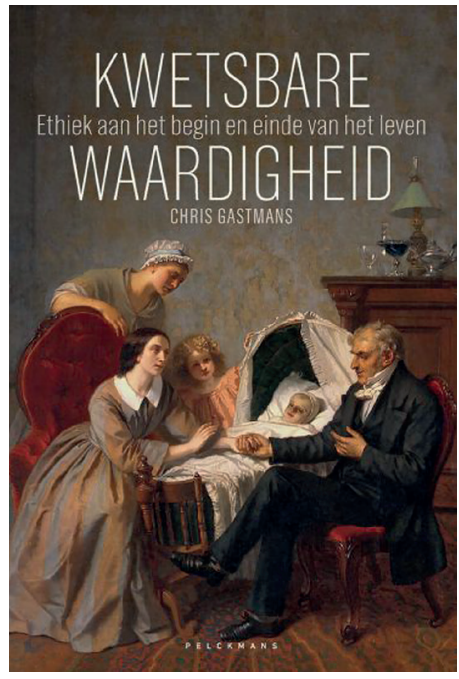

Dat de exponentieel toegenomen behandelmogelijkheden van de moderne geneeskunde tal van onuitgegeven uitdagingen inhouden voor ethisch verantwoorde zorg, was reeds langer duidelijk. Moeten we nog willen wat er allemaal kan? De Covid-19-crisis stelde deze vraag ongewild helemaal op scherp: wat kan menselijke waardigheid nog betekenen nu duidelijk geworden is dat "iedereen kwetsbaar" is (p. 189)? Chris Gastmans, hoogleraar medische ethiek (KU Leuven) en adviseur Zorgnet-Icuro, neemt een aantal fundamentele vragen als uitgangspunt en rode draad in wat een basiswerk is voor al wie zijn eigen zorgpraktijk aan het begin of het einde van het leven ethisch-kritisch wil aftoetsen.

Zijn aanpak, model en methode zijn tegelijk toegankelijk, gefundeerd en onderbouwd met de meest recente resultaten van kwalitatief en kwantitatief, ook empirisch onderzoek, waartoe hij zijn eigen bijdrage leverde. Gastmans zet zich af tegen de klassieke principebenadering van onder meer Beauchamp en Childress (Principles of Biomedical Ethics). Deze wordt ontmaskerd als te abstract, te procedureel en te exclusief toegespitst op de handeling en het geïsoleerde individu en onvoldoende op de ethische houding, de omgeving en de omstandigheden. Gastmans zoekt daarentegen resoluut aansluiting bij de concrete bestaanssituatie van de patiënt en van diegenen die hem omringen, "een bestaanssituatie die getekend wordt door ervaringen van kwetsbaarheid, zorgafhankelijkheid en (verlies van) waardigheid” (p. 24). Wat een 'ethiek van de gezondheidszorg' wil zijn, vertrekt derhalve van (1) de concreet beleefde ervaring van mensen, die voorwerp wordt van wat hij (2) een 'interpretatieve dialoog' noemt en (3) afgetoetst wordt aan 'de ethische standaard'. Ongeacht je eigen positie moet "er voldoende aandacht gaan naar het begrijpen van de verschillende standpunten" die in de dialoog tussen de patiënt, de omgeving en het multidisciplinaire team worden uitgedrukt (p. 27). Het doel is de toets aan een ethische standaard die elk voor zich hanteert en waarvoor de auteur ons meeneemt in zijn persoonlijke waardenkader: "Door het algemeen menselijke karakter van de christelijke waarden ben ik ervan overtuigd dat aan de christelijke traditie bakens te ontlenen zijn waarbinnen je in een pluralistische context een zoektocht naar het goede kunt beginnen" (p. 29). Drie aspecten van het menszijn hanteert hij daarbij als leidraad: kwetsbaarheid, zorg en waardigheid - dit laatste scherp ontleed - en hij verbindt deze met morele houdingen als aandachtigheid, verantwoordelijkheid, betrouwbaarheid en respect. 


\section{tvgg. pvasen Bespere}

Dit model van 'waardigheidsbevorderende zorg' werkt de auteur vervolgens uit voor 6 domeinen van de gezondheidszorg: prenatale diagnostiek (cf. NIPT), zwangerschapsafbreking en levenseindezorg in de neonatologie (als ethische thema's aan het begin van het leven), levenseindezorg in de psychiatrie (inclusief crustatieve of schelpzorg), seksualiteit in de ouderenzorg en levensmoeheid aan het einde van het leven. Telkens vertrekt hij van de kennis van de relevante medische en zorginhoudelijke aspecten die betrekking hebben op het thema. Vervolgens illustreert hij met een casusbeschrijving hoe cruciaal het is om aandachtig te luisteren naar de concreet beleefde ervaring (van de patiënt, maar ook van de zorgverleners) om dan - en pas dan - te komen tot waardenopties, ethische afwegingen en aanbevelingen. Hij doet dit met grote aandacht voor de kwaliteit van het proces zelf van de ethische besluitvorming en dit voor alle betrokkenen: de patiënt, de naasten, de zorgverleners, de zorgvoorzieningen en de samenleving.

Door aldus alle betrokken actoren in rekening te nemen, illustreert hij de grenzen van de autonomie-ethiek en brengt hij op elke bladzijde 'respect voor autonomie in verbondenheid' of 'relationele autonomie' in de praktijk (p. 67), een begrip waarmee hij de traditie van het Leuvense personalisme herijkt. Het uitgangspunt is een authentiek respect voor de wil van de patiënt. De zorgrelatie leert dat die echter nooit absoluut kan zijn en niet enkel waar het om - geheel, gedeeltelijk of mogelijk - wilsonbekwame personen gaat uit de 6 hierboven genoemde domeinen (ongeboren kinderen, neonaten, psychiatrische patiënten of personen met dementie). Fundamenteler en alleen in schijn paradoxaler: relaties, alsook ondersteuning door de omgeving en zorgverleners helpen net de zelfbeschikking van het individu te realiseren en zijn er "juist de essentiële voorwaarde toe". "Autonomie in verbondenheid impliceert dat mensen hun verantwoordelijkheid voor elkaar opnemen" (ib.).

Voor wie vindt dat dit niet voldoende hip of flitsend klinkt, zij verwezen naar dezelfde boodschap, 'autonomie in relatie', door de Vlaamse psychiater en filosoof Damiaan Denys, hoogleraar psychiatrie aan de Universiteit van Amsterdam, bij gelegenheid van het Paleissymposium 2021 aan het Koninklijk Paleis Amsterdam (https://www.paleisamsterdam.nl/paleissymposium) (www.damiaandenys.com). Gastmans werkt het overtuigend uit, zonder te vervallen in enerzijds principiële rigiditeit of anderzijds psychologisering van de ethiek: een welgekomen, niet-polariserende, heldere stem.

P. Vanden Berghe PhD, Leuven 